\title{
Performance and Differences in Grading Practices Among Undergraduates at Business Schools
}

\section{Leiv Opstad (iD), ${ }^{*}$}

\author{
${ }^{1}$ Norwegian University of Science and Technology, NTNU Business School, NO-7491 Trondheim, Norway
}

\author{
ARTICLE HISTORY \\ Received: Mar. 24, 2021 \\ Revised: Sep. 15, 2021 \\ Accepted: Sep. 22, 2021 \\ Keywords: \\ Grading standard, \\ Business School, \\ Performance, \\ Mathematical skills, \\ Gender.
}

\begin{abstract}
If the ranking of students is based on grade scores independent of the selected college or university, it is critical to have an equal national measurement standard. It is a challenge to ensure this if there is a substantial difference in the composition of the students and enrolment requirements among colleges. Based on three different types of colleges in Norway merged into one unit in 2019, this paper examines the grading practices before and after the fusion. By using a regression model to predict the grade depending upon students' academic skills, one can identify different grading practices for the three independent schools and compare the results after they become one unit with identical exams and a common evaluation. The results show significantly more lenient grading practices at small colleges with low entry criteria and that the evaluation is more random, depending upon the instructor. Furthermore, this paper confirms that the grade point average (GPA) from upper secondary school, mathematical abilities and gender are strongly correlated with success in business studies.
\end{abstract}

\section{INTRODUCTION}

The purpose of this paper is to analyse whether there are different grading practices among schools within business education in Norway and to examine which factors can explain students' performance in business courses. Some countries rank students depending on which institution they have attended. Norway have chosen a different approach. For the same course, there should be identical evaluation regardless of which university or college the student is graduated from.It is challenging to secure such a scheme. We'll take a closer look at this issue in thus article. The research suggests that there are significant differences internationally in grading practice (Broockhart et al., 2016).

The grading system among undergraduates is critical since the ranking of students depends on the grade scores. A grading design that measures students' knowledge and skills would be a good tool for ranking in future studies and would provide the desired information to future employers. Independently of the institution, it is assumed that two students who achieve the same level of result should receive identical grades. The students are ranked according to their grade scores, independently of which college or university they have attended. To ensure this,

\footnotetext{
*CONTACT: Leiv OPSTAD $₫$ leiv.opstad@ntnu.no NTNU Business School, NO-7491 Trondheim, Norway

Norwegian University of Science and Technology,
} 
the Norwegian Ministry of Education has used substantial resources to develop identical grading habits all over the country. All colleges and universities should have the same grading evaluation by following the ECTS (European Credit Transfer and Accumulation System) grading scale system (see Table 1). Two students having the same grade shall perform equally, independently of the chosen college. Grade C shall have the same meaning for the same business course regardless of which school the student has attended and regardless of the student's abilities and academic skills.

It is difficult to justify a system in which students are treated differently depending on background and school and get different grades even there is an equal performance, as long as there is no ranking of the schools. Hence, the grading standard system should compensate for differences across institutions provided that there is no ranking based upon which school the student has attended. The distribution of grades is at the national level (Table 1). The grade for the mean student will vary depending on the performance of the students at the different schools. Hence, the grading system does not give the correct information about the candidates 'qualifications. Without further knowledge of the different education institutions the employers do not have the correct qualifications. This can lead to a principal agent problem with asymmetric information.

Table 1. The Grading System (on National level).

\begin{tabular}{lccl}
\hline Grade & Per-cent & Description & $\begin{array}{l}\text { General, qualitative description of the evaluation criteria (see: } \\
\text { https://www.ntnu.edu/studies/grading) }\end{array}$ \\
\hline F & Fail & $\begin{array}{l}\text { A performance that does not meet the minimum academic } \\
\text { criteria. The candidate demonstrates an absence of both } \\
\text { judgement and independent thinking. }\end{array}$ \\
\hline E & 10 & Sufficient & $\begin{array}{l}\text { A performance that meets the minimum criteria but no more. } \\
\text { The candidate demonstrates a very limited degree of judgement } \\
\text { and independent thinking. }\end{array}$ \\
\hline D & 25 & Satisfactory & $\begin{array}{l}\text { A satisfactory performance but with significant shortcomings. } \\
\text { The candidate demonstrates a limited degree of judgement and } \\
\text { independent thinking. }\end{array}$ \\
\hline C & 30 & Good & $\begin{array}{l}\text { A good performance in most areas. The candidate demonstrates } \\
\text { a reasonable degree of judgement and independent thinking in } \\
\text { the most important areas. }\end{array}$ \\
\hline B & 25 & Very good & $\begin{array}{l}\text { A very good performance. The candidate demonstrates sound } \\
\text { judgement and a very good degree of independent thinking }\end{array}$ \\
\hline A & 10 & Excellent & $\begin{array}{l}\text { An excellent performance, clearly outstanding. The candidate } \\
\text { demonstrates excellent judgement and a high degree of } \\
\text { independent thinking. }\end{array}$ \\
\hline
\end{tabular}

\subsection{Facors Behind Students' Success in Business Courses}

Academic ability is a key factor for success in higher education. A variable that can encapsulate this dimension is grade point average (GPA) scores from upper secondary schools. According to Grove et al. (2006), GPA scores are a proxy estimate of students' academic aptitude in economic education. Many studies have found a positive correlation between GPA and achievement in business studies (Jones et al., 2013; Opstad \& Årethun, 2020a). Uyar and Güngörmüş (2011) reported that GPA from upper secondary school was the strongest predictor of success in finance and accounting courses. In comparing GPA with attendance in the courses, the authors observed only a weak positive link between attendance and performance. The association between GPA and success is also substantial and positive for marketing courses 
(Marcal et al., 2005). Students with high GPAs also have success in introductory management courses (Brookshire \& Palocsay, 2004).

Another key determinant for success in business courses is mathematical skills Blaylock \& Lacewell, 2008; Opstad, 2018). Mathematics is a valuable factor for doing analyses in quantitative courses. Hence, there is a strong significant connection between mathematical abilities and performance in quantitative business courses (Ballard \& Johnson, 2004; Mallik \& Lodewijks, 2010; Opstad \& Årethun, 2019; Uyar \& Güngörmüş, 2011). Students' mathematical background seems to be a crucial instrument for managing these subjects. Alcock et al. (2008) and Opstad (2018) also found a positive correlation between mathematical knowledge and performance in non-quantitative business courses like management and marketing even though there are no mathematical tools in presentations in these fields. The reason might be that mathematical strength improves the students' ability to analyse and develop a good structure in their performance in non-analytical courses; however, the mathematical background is not as essential as in quantitative courses (Alcock et al., 2008).

Gender also matters in business courses. Krishna and Orhun (2020) found that females have less success in the quantitative courses, even the female students who have improved their performance over the past years. On the other hand, females seem to perform better in nonquantitative courses (Volchok, 2019). Opstad and Årethun (2020b) observed that women got significant higher scores in marketing course than men.

Other factors linked to performance in business courses are personal characteristics and students' effort. Numerous articles have studied the connection between personal traits and academic success (Trapman et al., 2007). Study effort correlates positively to achievements in business courses (Bonesrønning \& Opstad, 2012; Stinebrickner \& Stinebrickner, 2008).

Teacher quality seems to be strongly associated with student success. Darling- Hammond (2000) reported a strong positive connection between instructors' skills and student achievement. Odden et al. (2004) found that teachers' qualifications have an impact on students' learning and performance. Other studies have also confirmed this result. The instructors matter, but the influence on student success varies (Bardach \& Klassen, 2020).

\subsection{What Can Explain Different Grading Practices}

In Norway, essays and constructed response questions comprise a considerable part of the final exams. This is in contrast to American colleges where a multiple-choice question format is the main style of examination (Walstad \& Miller, 2016). Essay questions make it difficult to ensure equal grading practices across institutions, and many countries experience these same challenges. According to Beenstock and Feldman (2018), differential grading across colleges seems to be the norm rather than the exception.

Admission standards play a critical role to ensure high standards in study programmes (Lawrence \& Pharr, 2003). Even if there are similar school enrolment criteria, there might be substantial differences in the qualifications of the students. Some colleges welcome all qualified applications, while others only accept students with high GPAs since there are considerably more applicants than places available. Hence, it is a competition among the students to get an offer of acceptance. Furthermore, an academic school with a good reputation attracts qualified students (Mayer-Foulkes, 2002). Therefore, the differences in enrolment qualifications might remain or even be stronger over time. Well qualified students tend to apply to colleges which accept only applications with good academic skills and high entrance scores. This might cause a bias against programmes which are not attractive and include academically weaker students (Godor, 2017). One might be tempted to give higher grades compared to schools with more popular programmes. Marini et al. (2018) found a substantial difference in grading practices in certain disciplines, depending upon the qualification of the students. According to Godor (2017) 
and Opstad (2020), the result can be different grading considerations across the institutes and programmes at the same faculty, depending upon the composition of the students. Academically stronger students tend to get a more stringent grading evaluation.

The role of teachers is crucial for the grading standard (Cheng et al., 2020; Godor, 2017). The instructors' considerations of students' contributions and performance are essential for the students' grades. Bonesrønning (1999) reports that the grading practice of the lecturers are directly linked to their characteristics, such as preferences, attitudes, gender, age, skills and education. Even if the goal is to have an equal grading system, different kinds of teachers can result in differing grading standards.

The effect of a national norm of grading practices implies that courses with students with poor academic skills will result in rather low average grades. Having such students, both the instructor and the school can feel uncomfortable with such an outcome. One can therefore be tempted to follow more or less the composition of the ECTS grading system locally and disregard or not focus on the differences in students' entrance qualifications, and thus one gets less strict in the grading practices. More students achieve the letter grade A or B than they deserve according to the national schedule (see Table 1), which makes more students happy. Those schools can attract students who struggle to achieve enough points required for further studies. Lenient grading practices can also improve instructor ratings and student evaluations of their teacher (Hoefer et al., 2012). Faculty deans can use the grades as a proxy for the instructors' teaching abilities. Also, due to the financial system, colleges involving academically weaker students can be interested in rewarding students with better grades than the national norm. The colleges receive revenue from the Ministry of Education depending on how many students pass their courses. Therefore, the instructor, faculty dean and the administration can benefit from having a less stringent grading standard if the average student has rather low enrollment scores. This can lead to a misallocation of public funds (Bagues et al., 2008).

\subsection{Hypotheses}

Based on the previous research, we postulated the following hypotheses:

H1: There is a link between performance in business and the students' mathematical background, academic skills and gender.

H2: There are grading differences for equally qualified students among business schools in Norway.

Even though the goal is to have a national standard, local variations can cause diversity in the grading practices

\section{METHOD}

The data consisted of information about individual background variables and performance in four business courses at three different schools for 3 years: 2016, 2017 and 2019. Earlier on, there were three independent business institutions, but in 2018 , they united into one into join school. We will focus on students' outcome before and after the merger was completed. Furthermore, in 2019, an identical design was introduced for all courses with a common exam with same examiners. This makes it possible to compare the results before and after the fusion of the schools. Table 2 presents the data for 2016 and 2017. Since there are clear national standards on the content of the various courses, then there is little variation among the different schools. The pedagogical arrangement is quite identical across the institutions. The exam form is a 4 hour written exam based on response questions. On the other hand, it is the local lecturer who design the exam thesis and conducts the examination. But the rules are that a student should receive an identical grade with the same contribution regardless of institution. Data in this 
analysis make it possible to consider it one has managed to have such a grading system. This is administrative data and includes all students who took the exam in the actual courses.

Table 2. Descriptive Statistics.

\begin{tabular}{|c|c|c|c|c|c|c|c|c|}
\hline & \multicolumn{2}{|c|}{ All } & \multicolumn{2}{|c|}{ School A } & \multicolumn{2}{|c|}{ School B } & \multicolumn{2}{|c|}{ School C } \\
\hline & \multicolumn{2}{|c|}{ Mean St. Dev. } & \multicolumn{2}{|c|}{ Mean St. Dev. } & \multicolumn{2}{|c|}{ Mean St. Dev. } & Mean & St. Dev. \\
\hline Percent S-maths & $27.35 \%$ & & $34.73 \%$ & & $21.33 \%$ & & $9.6 \%$ & \\
\hline Percent N-maths & $16.70 \%$ & & $22.12 \%$ & & $9.33 \%$ & & $6.21 \%$ & \\
\hline Percent males & $46.80 \%$ & & $47.53 \%$ & & $40.00 \%$ & & $50.28 \%$ & \\
\hline $\begin{array}{l}\text { GPA Upper } \\
\text { Secondary School }^{1}\end{array}$ & 4.46 & 0.52 & 4.71 & 0.31 & 4.06 & 0.45 & 3.95 & 0.60 \\
\hline Microeconomics $^{2}$ & 2.58 & 1.53 & 2.97 & 1.41 & 1.26 & 1.51 & 2.50 & 1.55 \\
\hline Macroeconomics $^{2}$ & 2.75 & 1.48 & 2.87 & 1.37 & 2.67 & 1.72 & 2.39 & 1.50 \\
\hline Management $^{2}$ & 3.08 & 1.17 & 2.95 & 1.24 & 3.03 & 1.17 & 3.62 & 0.69 \\
\hline Marketing $^{2}$ & 2.83 & 1.27 & 2.77 & 1.23 & 2.73 & 1.26 & 3.52 & 1.29 \\
\hline $\mathrm{N}^{3}$ & 860 & & 547 & & 136 & & 177 & \\
\hline Notes. & $\begin{array}{ll}\text { 1) } & \text { The } \\
\text { 2) } & \text { Mea } \\
\text { 3) } & \text { The }\end{array}$ & $\begin{array}{l}\text { rrades ar } \\
\text { letter gi } \\
\text { lumbers }\end{array}$ & $\begin{array}{l}\text { rom } 1 \text { to } 6 \text {. } \\
\text { e }(0: F, 1 \text { : } \\
\text { ry dependi }\end{array}$ & $\begin{array}{l}2: D, 3 \\
g \text { on the }\end{array}$ & $\begin{array}{l}\text { 4: B, 5: A } \\
\text { ject. }\end{array}$ & & & \\
\hline
\end{tabular}

There are substantial differences between the three schools. School A is located in a rather big city where there is competition among students to gain access to the courses. Therefore, institution A has higher entrance requirement. The GPA from upper secondary school is therefore higher for business school A than for B and C (about three quarters higher) and the variations are also smaller (standard deviation for $\mathrm{A}$ is only 0.31 compared with 0.45 and 0.60 for the two others).

Students at upper secondary school can choose between three pathways in mathematics: practical mathematics (P-maths), mathematics for business and social science (S-maths) or mathematics for natural science (N-maths). P-mathematics is practical. The subjects in Smathematics contain functions, algebra and regression models. N-mathematics is most advanced and theoretical and includes issues like geometry and vectors. The students attending school A have considerably stronger skills in mathematics than those attending B or C. Notice also the variations in scores depending on the institution. Students from A outperform the other institutions in the quantitative courses (macroeconomics and microeconomics), while they tend to underperform in the non-quantitative courses. The mean student from A has the lowest score in management and about the same level as school B in marketing, while the average score for school $\mathrm{C}$ is almost one letter grade higher.

\subsection{The Model}

By using linear regression, we will analyse how the performances at each school are associated with explained variables of GPA, gender and mathematical skills (Model 1):

where,

$$
Y_{i j}=a_{0}+a_{1} X_{1}+a_{2} X_{2}+a_{3} X_{3}+a_{4} X_{4}+\varepsilon
$$

$Y_{i j}$ : grades in business course $\mathrm{i}$, institution $\mathrm{j}$;

$\alpha_{0}$ : constant; $\mathrm{X}_{1}$ : gender $(0: \mathrm{F}, 1: \mathrm{M}) ; \mathrm{X}_{2}$ : GPA from secondary upper school;

$\mathrm{X}_{3}$ : dummy variable for having chosen $\mathrm{N}$-mathematics ( 0 : not chosen, 1 : chosen); 
$\mathrm{X}_{4}$ : dummy variable for having chosen $\mathrm{S}$ - mathematics (0: not chosen, 1: chosen)

The literature indicates that GPA from secondary upper school, gender and mathematical skills affect students' performance in business courses. Hence, they are chosen as independent variables.

In Model 2 we will use the result to predict performances in the different schools by using dummy variables. The applied Model 2 is:

where,

$$
Y_{i}=a_{0}+a_{1} X_{1}+a_{2} X_{2}+a_{3} X_{3}+a_{4} X_{4}+a_{5} X_{5}+a_{6} X_{6}+\varepsilon
$$

Yi: grades in business course i. (0: F, 1: E, 2: D, 3: C, 4: B, 5: A);

$\alpha_{0}$ : constant; $\mathrm{X}_{1}$ : gender $(0: \mathrm{F}, 1: \mathrm{M}) ; \mathrm{X}_{2}$ : GPA from secondary upper school;

$\mathrm{X}_{3}$ : dummy variable for having chosen $\mathrm{N}$-mathematics ( 0 : not chosen, 1: chosen);

$\mathrm{X}_{4}$ : dummy variable for having chosen $\mathrm{S}$ - mathematics ( 0 : not chosen, 1 : chosen);

$\mathrm{X}_{5}$ : dummy variable for belonging to school $\mathrm{B}$ (0: not institution $\mathrm{B}, 1$ : school $\left.\mathrm{B}\right)$;

$\mathrm{X}_{6}$ : dummy variable for belonging to school $\mathrm{C}$ (0: not school $\mathrm{C}, 1$ : school $\mathrm{C}$; $)$

$\varepsilon:$ stochastic error

To avoid multicollinearity, no dummy variables for school A were included in the regression model, and this group will belong to the reference category.

\section{RESULT / FINDINGS}

\subsection{Result from the Regression Model (Tables 3-6)}

A comparison of the three institutions shows many similarities, such as there is a considerable correlation between GPA score and success regardless of the school. The findings confirm hypothesis $1(\mathrm{H} 1)$. There is a strong correlation between GPA from upper secondary school and outcomes for all courses, but the impact is strongest for the quantitative courses. Comparing microeconomics and marketing, the influence is about twice as big for microeconomics (Model 2). The values depend on the schools. For microeconomics, the unstandardised beta score is 1.37 for school A and around 1.0 for the other institutions.

Therefore, mathematical background from secondary upper school is a good predictor of performance in business courses. Mathematical skills are related to performance and especially in microeconomics ( $\beta=0.54$ for S-maths and 0.44 for N-maths, Model 2). There is also a significant link between mathematical skills and success in marketing and management but a lower impact ( $\beta$ values are between 0.16 and 0.35 , and they are higher for $\mathrm{N}$-mathematics than for S-mathematics).

The gender influence is in favour of males in macroeconomics and microeconomics, but the result is opposite for marketing and management (Model 2). Male students underperform compared with female peers.

There are also considerable variations in significance levels and impacts among the schools. For instance, in macroeconomics, $\mathrm{N}$-mathematics is strong related to the success of institution $\mathrm{C}(\beta=1.98)$ but negative and with no significant effect for institution A. There is no significant gender effect for $\mathrm{B}$ and $\mathrm{C}$ but a strong and significant one for $\mathrm{A}$. Looking at marketing, there is no association between mathematical background and scores for institution $\mathrm{B}$. N-mathematics has a significant impact for institution A but not for institution C. For S-mathematics, the opposite is the case. There is a high beta score $(\beta=0.71)$ and significance at the 10 percent level for $\mathrm{C}$ but a weak beta score and no significant impact for A. Some of the same differences occur for microeconomics and management. 
Table 3. Performance in Macroeconomics (unstandardised $\beta$ values, standard deviation in parantesis).

\begin{tabular}{|c|c|c|c|c|c|c|c|c|}
\hline & \multicolumn{2}{|c|}{ School A } & \multicolumn{2}{|c|}{ School B } & \multicolumn{2}{|c|}{ School C } & \multicolumn{2}{|c|}{ All (Model 2) } \\
\hline & $\beta$ & Sig. & $\beta$ & Sig. & $\beta$ & Sig. & $\beta$ & Sig. \\
\hline \multirow[t]{2}{*}{ Constant } & -22.25 & .021 & .489 & .687 & -.198 & .864 & -1.41 & .037 \\
\hline & $(0.97)$ & . & (1.208) & & (1.15) & & $(0.68)$ & \\
\hline \multirow[t]{2}{*}{ Gender } & .78 & .000 & .436 & .142 & .077 & .802 & .64 & .000 \\
\hline & $(0.13)$ & & $(0.30)$ & & $(0.31)$ & & $(0.11)$ & \\
\hline \multirow[t]{2}{*}{ S-maths } & .22 & .127 & .577 & .091 & 1.185 & .009 & .37 & .005 \\
\hline & $(0.14)$ & & $(0.34)$ & & $(0.44)$ & & (0.13) & \\
\hline \multirow[t]{2}{*}{ N-maths } & -.001 & .993 & .133 & .809 & 1.981 & .003 & .16 & .316 \\
\hline & $(0.16)$ & & $(0.13)$ & & $(0.64)$ & & $(0.16)$ & \\
\hline \multirow[t]{2}{*}{ GPA } & 1.00 & .000 & .478 & .101 & .633 & .031 & .81 & .000 \\
\hline & $(0.20)$ & & $(0.29)$ & & $(0.29)$ & & (0.14) & \\
\hline \multirow[t]{2}{*}{ Dummy B } & & & & & & & .50 & .003 \\
\hline & & & & & & & $(0.17)$ & \\
\hline \multirow[t]{3}{*}{ Dummy C } & & & & & & & .45 & .037 \\
\hline & & & & & & & $(0.21)$ & \\
\hline & $\begin{array}{r}\mathrm{N}= \\
\text { Adj. } \mathrm{R}\end{array}$ & $\begin{array}{l}7, \\
0.06\end{array}$ & $\begin{array}{c}\mathrm{N}= \\
\text { Adj. } \mathrm{R}^{2}\end{array}$ & 037 & $\begin{array}{r}\mathrm{N} \\
\text { Adj. } \mathrm{R}\end{array}$ & .176 & $\begin{array}{r}\mathrm{N} \\
\text { Adj. } \mathrm{R}\end{array}$ & 6.094 \\
\hline
\end{tabular}

Table 4. Performance in Microeconomics (unstandardised $\beta$ values,standard deviation in parentheses).

\begin{tabular}{|c|c|c|c|c|c|c|c|c|}
\hline & \multicolumn{2}{|c|}{ School A } & \multicolumn{2}{|c|}{ School B } & \multicolumn{2}{|c|}{ School C } & \multicolumn{2}{|c|}{ All (Model 2) } \\
\hline & $\beta$ & Sig. & $\beta$ & Sig. & $\beta$ & Sig. & $\beta$ & Sig. \\
\hline Constant & $\begin{array}{l}-3.85 \\
(0.94)\end{array}$ & .000 & $\begin{array}{l}-1.13 \\
(1.19)\end{array}$ & .343 & $\begin{array}{l}-1.19 \\
(0.90)\end{array}$ & .186 & $\begin{array}{l}-2.25 \\
(0.61)\end{array}$ & .000 \\
\hline Gender & $\begin{array}{l}.140 \\
(0.12) \\
\end{array}$ & .255 & $\begin{array}{c}.592 \\
(0.26) \\
\end{array}$ & .026 & $\begin{array}{c}.00 \\
(0.25) \\
\end{array}$ & .999 & $\begin{array}{c}.18 \\
(0.10) \\
\end{array}$ & .067 \\
\hline S-maths & $\begin{array}{c}.58 \\
(0.14)\end{array}$ & .000 & $\begin{array}{c}.194 \\
(0.31)\end{array}$ & .528 & $\begin{array}{c}.96 \\
(0.38)\end{array}$ & .012 & $\begin{array}{c}.54 \\
(0.19)\end{array}$ & .000 \\
\hline N-maths & .42 & .008 & $\begin{array}{l}.570 \\
(0.43)\end{array}$ & .189 & $\begin{array}{l}1.12 \\
(0.48\end{array}$ & .020 & $\begin{array}{c}.44 \\
(0.14)\end{array}$ & .002 \\
\hline GPA & $\begin{array}{c}1.37 \\
(0.20) \\
\end{array}$ & .000 & $\begin{array}{c}.495 \\
(0.29) \\
\end{array}$ & .088 & .89 & .000 & $\begin{array}{l}1.03 \\
(0.13) \\
\end{array}$ & .000 \\
\hline Dummy B & & & & & & & $\begin{array}{c}.95 \\
(0.16)\end{array}$ & .000 \\
\hline \multirow[t]{2}{*}{ Dummy C } & & & & & & & $\begin{array}{c}.51 \\
(0.17) \\
\end{array}$ & .002 \\
\hline & \multicolumn{2}{|c|}{$\begin{array}{c}\mathrm{N}=511, \\
\text { Adj. } \mathrm{R}^{2}=0.103\end{array}$} & \multicolumn{2}{|c|}{$\begin{array}{c}N=135, \\
\text { Adj. } R^{2}=0.048\end{array}$} & \multicolumn{2}{|c|}{$\begin{array}{c}\quad \mathrm{N}=94, \\
\text { Adj. } \mathrm{R}^{2}=0.195\end{array}$} & \multicolumn{2}{|c|}{$\begin{array}{c}\mathrm{N}=666, \\
\text { Adj. } \mathrm{R}^{2}=0.251\end{array}$} \\
\hline
\end{tabular}


Table 5. Performance in Marketing (unstandardised $\beta$ values,standard deviation in parentheses).

\begin{tabular}{|c|c|c|c|c|c|c|c|c|}
\hline & \multicolumn{2}{|c|}{ School A } & \multicolumn{2}{|c|}{ School B } & \multicolumn{2}{|c|}{ School C } & \multicolumn{2}{|c|}{ All (Model 2) } \\
\hline & $\beta$ & Sig. & $\beta$ & Sig. & $\beta$ & Sig. & $\beta$ & Sig. \\
\hline Constant & $\begin{array}{l}.45 .74 \\
(0.74)\end{array}$ & .542 & $\begin{array}{c}.26 \\
(0.66)\end{array}$ & .690 & $\begin{array}{c}1.12 \\
(0.79)\end{array}$ & .158 & $\begin{array}{c}.17 \\
(0.46)\end{array}$ & .712 \\
\hline Gender & $\begin{array}{c}-.24 \\
(0.10)\end{array}$ & .015 & $\begin{array}{c}-.41 \\
(0.15)\end{array}$ & .005 & $\begin{array}{l}-.070 \\
(0.24)\end{array}$ & .769 & $\begin{array}{c}-.27 \\
(0.08\end{array}$ & .001 \\
\hline S-maths & $\begin{array}{c}.15 \\
(0.12)\end{array}$ & .225 & $\begin{array}{c}-.02 \\
(0.25)\end{array}$ & .950 & $\begin{array}{c}.71 \\
(0.41)\end{array}$ & .086 & $\begin{array}{c}.13 \\
(0.11)\end{array}$ & .203 \\
\hline N-maths & $\begin{array}{c}.33 \\
(0.11)\end{array}$ & .004 & $\begin{array}{c}.01 \\
(0.19)\end{array}$ & .968 & $\begin{array}{c}.25 \\
(0.39)\end{array}$ & .527 & $\begin{array}{c}.26 \\
(0.09)\end{array}$ & .006 \\
\hline$\overline{\text { GPA }}$ & $\begin{array}{c}.50 \\
(0.15)\end{array}$ & .001 & $\begin{array}{c}.63 \\
(0.15)\end{array}$ & .000 & $\begin{array}{c}.59 \\
(0.19)\end{array}$ & .002 & $\begin{array}{c}.56 \\
(0.09)\end{array}$ & .000 \\
\hline Dummy B & & & & & & & $\begin{array}{c}.26 \\
(0.11)\end{array}$ & .015 \\
\hline Dummy C & & & & & & & $\begin{array}{c}1.13 \\
(0.15)\end{array}$ & .000 \\
\hline & $\begin{array}{l}\quad \mathrm{N}= \\
\text { Adj. } \mathrm{R}^{2}\end{array}$ & $\begin{array}{l}5, \\
0.039\end{array}$ & $\begin{array}{r}\mathrm{N}= \\
\text { Adj. } \mathrm{R}\end{array}$ & $\begin{array}{l}4, \\
0.97\end{array}$ & $\begin{array}{r}\mathrm{N} \\
\text { Adj. } \mathrm{R}\end{array}$ & 9.106 & $\begin{array}{l}\mathrm{N}= \\
\text { Adj. } \mathrm{R}\end{array}$ & 6 \\
\hline
\end{tabular}

Table 6. Performance in Management (unstandardised $\beta$ values,standard deviation in parentheses).

\begin{tabular}{|c|c|c|c|c|c|c|c|c|}
\hline & \multicolumn{2}{|c|}{ School A } & \multicolumn{2}{|c|}{ School B } & \multicolumn{2}{|c|}{ School C } & \multicolumn{2}{|c|}{ All (Model 2) } \\
\hline & $\beta$ & Sig. & $\beta$ & Sig. & $\beta$ & Sig. & $\beta$ & Sig. \\
\hline Constant & -.31 & -.31 & $\begin{array}{c}.80 \\
(0.59)\end{array}$ & .179 & $\begin{array}{c}2.57 \\
(0.40)\end{array}$ & .000 & $\begin{array}{c}.59 \\
(0.41)\end{array}$ & .147 \\
\hline Gender & -2.28 & -2.28 & $\begin{array}{c}-.48 \\
(0.12)\end{array}$ & .000 & $\begin{array}{c}.14 \\
(0.12)\end{array}$ & .245 & $\begin{array}{c}-.27 \\
(0.70)\end{array}$ & .000 \\
\hline S-maths & 1.10 & 1.10 & $\begin{array}{c}.30 \\
(0.21) \\
\end{array}$ & .152 & $\begin{array}{c}.22 \\
(0.17)\end{array}$ & .176 & $\begin{array}{c}.16 \\
(0.09) \\
\end{array}$ & .091 \\
\hline N-maths & 3.19 & 3.19 & $\begin{array}{c}.415 \\
(0.16)\end{array}$ & .010 & $\begin{array}{c}-.21 \\
(0.18)\end{array}$ & .251 & $\begin{array}{c}.35 \\
(0.09)\end{array}$ & .000 \\
\hline$\overline{\mathrm{GPA}}$ & 4.46 & 4.46 & $\begin{array}{c}.56 \\
(0.14)\end{array}$ & .000 & $\begin{array}{c}.26 \\
(0.10)\end{array}$ & .008 & $\begin{array}{c}.51 \\
(0.08)\end{array}$ & .000 \\
\hline Dummy B & & & & & & & $\begin{array}{c}.360 \\
(0.09)\end{array}$ & .000 \\
\hline Dummy C & & & & & & & $\begin{array}{c}1.14 \\
(0.13) \\
\end{array}$ & .000 \\
\hline & Ad & $\begin{array}{l}\mathrm{N}=5 \mathrm{~S} \\
=0.0\end{array}$ & & $\begin{array}{l}N=32 \\
2=0.1\end{array}$ & & $\begin{array}{l}=136, \\
=0.06\end{array}$ & & $\begin{array}{l}=1059, \\
=0.102\end{array}$ \\
\hline
\end{tabular}

The dummy variables are an indicator of grade standard differences in college $\mathrm{B}$ and $\mathrm{C}$ compared to A, adjusted for gender and enrolment qualifications (GPA and mathematical backgrounds). Using this method, there seems to be substantial differences in grading practices. Students of the same gender and with the same entrance qualifications receive at institution $C$ at least one letter grade better in in management $(\beta=1.14)$ and marketing $(\beta=1.13)$ than at institution A. For institution B, the difference is much lower for these two courses ( $\beta$ around $0.3)$. For macroeconomics, this gap is around 0.5, the same difference that exists for microeconomics for college $\mathrm{C}$. For college $\mathrm{B}$, the grading practice has been very strict in microeconomics. 


\subsection{Results from Common Exam After 2018 (Tables 7-9)}

After the fusion in 2018, there was common design for courses with identical exams and grading standard across the campuses after 2019. Tables 7 to 9 present the results for three of the subjects (not available for macroeconomics due to corona and no written exam with grades).

Table 7. Microeconomics Performance Before (2016-2017) and After Fusion (2019).

\begin{tabular}{|c|c|c|c|c|c|c|c|c|c|c|c|c|c|c|c|}
\hline \multirow{3}{*}{ Letter Grade } & \multicolumn{5}{|c|}{ School A } & \multicolumn{5}{|c|}{ School B } & \multicolumn{5}{|c|}{ School C } \\
\hline & \multicolumn{2}{|c|}{ Before fusion } & \multicolumn{2}{|c|}{ After fusion } & \multirow[b]{2}{*}{ Diff. } & \multicolumn{2}{|c|}{ Before fusion } & \multicolumn{2}{|c|}{ After fusion } & \multirow[b]{2}{*}{ Diff. } & \multicolumn{2}{|c|}{ Before fusion } & \multicolumn{2}{|c|}{ After fusion } & \multirow[b]{2}{*}{ Diff. } \\
\hline & $\mathrm{N}$ & Percent & $\mathrm{N}$ & Percent & & $\mathrm{N}$ & Percent & $\mathrm{N}$ & Percent & & $\mathrm{N}$ & Percent & $\mathrm{N}$ & Percent & \\
\hline $\mathrm{F}$ & 43 & 7.9 & 16 & 4.3 & -3.6 & 68 & 45.3 & 10 & 8.3 & -37 & 31 & 17.5 & 20 & 17.5 & 0 \\
\hline $\mathrm{E}$ & 45 & 8.2 & 24 & 6.4 & -1.8 & 29 & 19.3 & 30 & 24.8 & 5.5 & 16 & 9 & 25 & 21.9 & 12.9 \\
\hline $\mathrm{D}$ & 81 & 14.8 & 80 & 21.3 & 6.5 & 25 & 16.7 & 32 & 26.4 & 9.7 & 30 & 16.9 & 24 & 21.1 & 4.2 \\
\hline $\mathrm{C}$ & 172 & 31.4 & 118 & 31.5 & 0.1 & 10 & 6.7 & 36 & 29.8 & 23 & 49 & 27.7 & 29 & 25.4 & -2.3 \\
\hline $\mathrm{B}$ & 131 & 23.9 & 120 & 32 & 8.1 & 10 & 6.7 & 6 & 5 & -2 & 36 & 20.3 & 13 & 11.4 & -8.9 \\
\hline A & 75 & 13.7 & 17 & 4.5 & -9.2 & 8 & 5.3 & 7 & 5.8 & 0.5 & 15 & 8.5 & 3 & 2.6 & -5.9 \\
\hline Sum & 547 & 100 & 375 & 100 & & 150 & 100 & 121 & 100 & & 177 & 100 & 114 & 100 & 0 \\
\hline Mean $^{1}$ & 2.97 & & 2.94 & & 0.03 & 1.26 & & 2.15 & & -0.99 & 2.5 & & 1.99 & & 0.51 \\
\hline
\end{tabular}

1 F: 0, E: 1, D: 2, C: 3, B: 4, A: 5

Table 8. Management, Performance Before (2016-2017) and After Fusion (2019).

\begin{tabular}{|c|c|c|c|c|c|c|c|c|c|c|c|c|c|c|c|}
\hline \multirow[b]{3}{*}{ Letter Grade } & \multicolumn{5}{|c|}{ School A } & \multicolumn{5}{|c|}{ School B } & \multicolumn{5}{|c|}{ School C } \\
\hline & \multicolumn{2}{|c|}{ Before fusion } & \multicolumn{2}{|c|}{ After fusion } & \multirow[b]{2}{*}{ Diff. } & \multicolumn{2}{|c|}{ Before fusion } & \multicolumn{2}{|c|}{ After fusion } & \multirow[b]{2}{*}{ Diff. } & \multicolumn{2}{|c|}{ Before fusion } & \multicolumn{2}{|c|}{ After fusion } & \multirow[b]{2}{*}{ Diff. } \\
\hline & $\mathrm{N}$ & Percent & $\mathrm{N}$ & Percent & & $\mathrm{N}$ & Percent & $\mathrm{N}$ & Percent & & $\mathrm{N}$ & Percent & $\mathrm{N}$ & Percent & \\
\hline $\mathrm{F}$ & 29 & 4.6 & 14 & 3.7 & -0.9 & 14 & 4 & 62 & 29.1 & 25 & 0 & 0 & 16 & 11.3 & 11.3 \\
\hline $\mathrm{E}$ & 49 & 7.8 & 54 & 14.4 & 6.6 & 22 & 6.3 & 33 & 15.5 & 9.2 & 0 & 0 & 23 & 16.2 & 16.2 \\
\hline $\mathrm{D}$ & 122 & 19.4 & 55 & 14.6 & -4.8 & 64 & 18.2 & 40 & 18.8 & 0.6 & 9 & 4.9 & 44 & 31 & 26.1 \\
\hline $\mathrm{C}$ & 205 & 32.6 & 109 & 29 & -3.6 & 113 & 32.1 & 53 & 24.9 & -7 & 63 & 34.6 & 29 & 20.4 & -14.2 \\
\hline B & 171 & 27.2 & 94 & 25 & -2.2 & 119 & 33.8 & 23 & 10.8 & -23 & 98 & 53.8 & 22 & 15.5 & -38.3 \\
\hline $\mathrm{A}$ & 62 & 8.3 & 50 & 13.3 & 5 & 20 & 5.7 & 2 & 0.9 & -5 & 12 & 6.6 & 8 & 5.6 & -1 \\
\hline Sum & 628 & & 376 & 100 & & 352 & 100 & 213 & 100 & & 182 & 100 & 142 & 100 & \\
\hline Mean $^{1}$ & 2.95 & & 2.97 & & 0.02 & 3.03 & & 1.76 & & 1.17 & 3.62 & & 2.61 & & 0.99 \\
\hline
\end{tabular}

${ }^{1}$ F: 0, E: 1, D: 2, C: 3, B: 4, A: 5 
Assuming that the composition of students remains the same between the institutions, it gives a picture of how different enrolment qualifications and other differences influence the grade levels with identical exams with the same grade standards. School A has quite stable distributions and grade means before and after the fusion for all three subjects. For school B and C, there are considerable changes in mean grades and the spread of the grades, with the exception of marketing for school B. With the exemption of microeconomics from institution B, the mean grades from before and after the fusion decreased by a half to more than one letter grade. The effect is opposite for microeconomics from school B; the mean grade went up from 1.26 to 2.15

Table 9. Marketing Performance Before (2016-2017) and After Fusion (2019).

\begin{tabular}{|c|c|c|c|c|c|c|c|c|c|c|c|c|c|c|c|}
\hline \multirow[b]{3}{*}{$\begin{array}{l}\text { Letter } \\
\text { Grade }\end{array}$} & \multicolumn{5}{|c|}{ School A } & \multicolumn{5}{|c|}{ School B } & \multicolumn{5}{|c|}{ School C } \\
\hline & \multicolumn{2}{|c|}{ Before fusion } & \multicolumn{2}{|c|}{ After fusion } & \multirow[b]{2}{*}{ Diff. } & \multicolumn{2}{|c|}{ Before fusion } & \multicolumn{2}{|c|}{ After fusion } & \multirow[b]{2}{*}{ Diff. } & \multicolumn{2}{|c|}{ Before fusion } & \multicolumn{2}{|c|}{ After fusion } & \multirow[b]{2}{*}{ Diff. } \\
\hline & $\mathrm{N}$ & Percent & $\mathrm{N}$ & Percent & & $\mathrm{N}$ & Percent & $\mathrm{N}$ & Percent & & $\mathrm{N}$ & Percent & $\mathrm{N}$ & Percent & \\
\hline F & 49 & 7.5 & 11 & 3.2 & -4.3 & 22 & 7 & 16 & 9.2 & 2.2 & 4 & 2.5 & 4 & 5.1 & 2.6 \\
\hline $\mathrm{E}$ & 46 & 7 & 16 & 4.6 & -2.4 & 31 & 9.8 & 17 & 9.8 & 0 & 13 & 8.3 & 7 & 9 & 0.7 \\
\hline $\mathrm{D}$ & 132 & 20.1 & 92 & 26.4 & 6.3 & 60 & 19 & 31 & 17.9 & -1 & 13 & 8.3 & 27 & 34.6 & 26.3 \\
\hline $\mathrm{C}$ & 240 & 36.5 & 143 & 41.1 & 4.6 & 120 & 38.1 & 67 & 38.7 & 0.6 & 30 & 19.1 & 25 & 32.1 & 13 \\
\hline B & 161 & 24.5 & 71 & 20.4 & -4.1 & 62 & 19.7 & 39 & 22.5 & 2.8 & 62 & 39.5 & 14 & 17.9 & -21.6 \\
\hline A & 29 & 4.4 & 15 & 4.3 & -0.1 & 20 & 6.3 & 3 & 1.7 & -5 & 35 & 22.5 & 1 & 1.3 & -21.2 \\
\hline Sum & 657 & 100 & 348 & 100 & & 315 & 100 & 173 & 100 & & 157 & 100 & 78 & 100 & \\
\hline Mean $^{1)}$ & 2.77 & & 2.83 & & -0.06 & 2.73 & & 2.60 & & 0.13 & 3.52 & & 2.52 & & 1.00 \\
\hline
\end{tabular}

${ }^{1}$ F: 0, E: 1, D: 2, C: 3, B: 4, A: 5 
Table 10. Comparing Predicted Grade Before the Fusion (2016-2017) With Actual Grade After the Fusion (2019) for the Three Schools A, B and C.

\begin{tabular}{lcccccccc}
\hline & \multicolumn{3}{c}{$\begin{array}{l}\text { Data from 2016-2017 and applying result } \\
\text { from Model 2 }\end{array}$} & \multicolumn{3}{c}{$\begin{array}{c}\text { Data from common exam } \\
\text { 2019/2020 }\end{array}$} \\
\cline { 2 - 10 } & \multicolumn{3}{c}{ Letter Grade $^{1}$} & \multicolumn{2}{c}{$\begin{array}{c}\text { Predicted } \\
\text { Grade }^{2}\end{array}$} & \multicolumn{3}{c}{ Actual Grade } \\
\hline Course & A & B & C & B & C & A & B & C \\
\hline Macroeconomics & 2.87 & 2.67 & 2.39 & 2.17 & 1.94 & & Missing data & \\
\hline Microeconomics & 2.97 & 1.26 & 2.50 & 2.21 & 1.99 & 2.94 & 2.15 & 1.99 \\
\hline Marketing & 2.77 & 2.73 & 3.52 & 2.47 & 2.39 & 2.83 & 2.60 & 2.52 \\
\hline Management & 2.95 & 3.03 & 3.62 & 2.67 & 2.48 & 2.97 & 1.76 & 2.61 \\
\hline
\end{tabular}

${ }^{1} \mathrm{~F}: 0, \mathrm{E}: 1, \mathrm{D}: 2, \mathrm{C}: 3, \mathrm{~B}: 4, \mathrm{~A}: 5 \quad{ }^{2}$ Actual grade $-\beta$ (dummy variable)

\subsection{Comparing the Predictors From Model 2 With tge Actual Performance After Fusion}

Table 10 presents the predicted grade from schools depending on entry qualifications and gender (Model 2) and comparing this with the actual differences after the fusion. If we disregard management from school B, the calculated differences from Model 2 give a good predictor of the students' actual mean differences from the three campuses depending upon variations in academic skills. Hypotheses 2 (H2) is confirmed.

\section{DISCUSSION and CONCLUSION}

The results in this study are mainly in line with previous research. GPA is a proxy of academic skills. The GPA scores from school A are between a half and one grade higher than the two other schools. The variations are also lower at A than at B and C. From Model 2, we notice there is a strong positive correlation between GPA and performance in business courses. The associations are stronger for the quantitative courses ( $\beta$ around 1.0) than for the non-quantitative courses ( $\beta$ around 0.5). GPA is a good predictor for success in business courses (Brookshire \& Palocsay, 2005). With similar grade standards across the colleges, this will influence the grading levels. This is the main reason why students from school A deserve higher mean grades than for the two other schools. Another key factor is mathematical background. Table 2 shows that a higher percent of students from A have more theoretical mathematics compared to the two other schools. Especially at school C, few students have a background in advanced mathematics. Around 85 percent have only practical mathematics (P-maths, the alternative to $\mathrm{N}$ - and S-maths). Mathematical skills are linked to success in business studies and especially in quantitative courses (Mallik \& Lodewijks, 2010). This study confirms this connection with significant positive $\beta$ values for all courses (Model 2). The impact varies depending upon S- or $\mathrm{N}$-maths and quantitative and non-quantitative courses. For micro- and macroeconomics, the $\beta$ value is strongest for S-maths. The explanation might be that S-mathematics are adapted and intended for business students. For marketing and management, however, the impact is strongest for $\mathrm{N}$-mathematics. In those courses, one does not use mathematical formulas in the presentation of the subjects. Therefore, one does not need the mathematical tools learned by studying theoretical mathematics. However, studying N-mathematics helps students improve the design and structure of written essays in marketing and management. Hence, the reward in non-quantitative courses is higher grade scores. This result is similar to the finding of Brookshire and Palocsay (2005). 
This study shows that gender still matters. There is a plenty of literature on the topic of gender and success in business and economics courses and with some mixed results (Johnson et al., 2014). Even though the gender gap seems to be lessening, there is still a tendency for males to perform better in quantitative courses (Borde, 2017; Mavruk, 2019). On the other hand, many studies show that females outperform males in non-quantitative business courses (Friday et al., 2006; Volchok, 2019). Gender differences in preferences and personal characteristics can probably explain some of the gender gap (Chevalier, 2002).

It looks like there is a different practice among the quantitative and non-quantitative courses, especially for campus $\mathrm{C}$. In the non-quantitative courses, the students get higher scores at institution $\mathrm{C}$ than at institution A despite the lower entrance qualification. Our model suggested the grade should be about one letter grade lower if one used the same evaluation and standard as at school $\mathrm{A}$ (with a dummy value of $\beta=1.13$ for marketing and 1.14 for management). This may indicate that one instructor at institution $\mathrm{C}$ was not aware of having less qualified students in marketing and management or that one just decided to use ECTS locally. This implies that a more lenient grading practice was used than that in accordance with the national advice. For campus $\mathrm{B}$, the mean grades in non-quantitative courses were lower than for school A before the fusion, but it was not enough to catch up the differences in academic skills ( $\beta$ is around 0.3).

The mean grades for quantitative courses were substantially lower at schools B and $\mathrm{C}$ than at school A. The divergence, however, was not sufficient to explain the qualification differences. The grading habit shows a difference of a half letter grade, but Model 2 and the results of the identical exam after the fusion suggest that the difference should be around one letter grade due to the different level of academic abilities. The exception is microeconomics at school B where this study suggests the instructor had been too strict. Findings from model 2 indicate that the students on average deserve almost a higher score by one letter grade $(\beta=-0.95)$. With the identical exam, the mean score for this subject increased almost the same (from 1.26 to 2.15, Table 6).

A reason for different grading practices for quantitative and non-quantitative courses could be due to the characteristics of the subjects (Beenstock \& Feldman, 2018). Quantitative courses are easier to grade since there normally is only one correct answer. Therefore, it is easy to judge the qualifications. By contrast, in non-quantitative subjects, one can present the essay differently and various presentations and solutions can achieve high scores. There is often more than one way to provide excellent answers. Hence, the instructor can be more likely to give students the benefit of the doubt and reward them if in doubt. Notice also that the results from this study indicated different grading practice between school B and $\mathrm{C}$ in management and marketing in 2016-2017.

The results from the regression model (Model 2) seem to be a good predictor of the variation in grading practices among the schools. The actual grading differences after the fusion for the three subject are consistent with the calculated gap between the schools before the fusion but with the exception of management for school B. One reason might be that after the fusion the design of the common exam changed. The instructor did not adjust the course programme to align with this. Therefore, the students at school B did not prepare for the modified exam devised after the fusion.

Although the goal is to apply similar grading practices regardless of the admission criteria and colleges, this study reports that this is not the case. This supports the conclusion of Møen and Tjelta (2010). The composition of the student population influences grading practices, as it is easier to achieve good grades with undergraduates with weaker qualifications. The instructors are less strict in grading if the students are academically weaker. Two students with equal qualities can expect to get different grades depending upon their peers. At school B and C, it was possible for a student to achieve the same result as from school A with less effort. An 
average student could expect to improve their scores by choosing a college with low admission standards, and the divergences are huge. A possible explanation for the divergence from the national standard is the self-interest of students, instructors and college administration. Students achieve better grades, and this provides more opportunities for further studies and careers. The instructor can verify good grades, which are indicators of good teaching performance. The dean and the college administration can report good results, which generates more funds from the Ministry of Education and can attract more students.

The policy in Norway is very clear: the directive states that similar students shall receive the same scores regardless of the selected campus, composition of student population and enrolment criteria. The effect of different grading standards is that it gives a wrong signal when applying for work or further studies because the ranking will be incorrect. Therefore, some students are offered entry to programmes at the expense of better-qualified applicants. This is especially true if there are different practices among undergraduate programmes depending on the campus, as the composition of students in master's programmes will be wrong. Skilled students can be rejected by campuses with strict grading habits, resulting in an ineffective use of resources. This study shows that there are good reasons for applying the same exam regardless of the campus, and it probable that the university management was aware of this. Therefore, it was necessary for exams with same instructors to be evaluated by them in order to ensure there would be no differences in grading practice. From the current data, it appears that there were substantial differences in instructors' grading practices and evaluation. Therefore, it is no coincidence that our research suggests substantial differences in practices at small colleges. Both the academical environment and colleagues to notice and adjust for obviously poor judgement in grading are lacking. As examples, the instructor in microeconomics at college $\mathrm{B}$ has apparently been too strict, and the instructors at college $\mathrm{C}$ have been too lenient in assessing the grades in management and marketing.

Another issue is how a common exam for the three campuses with such big differences in enrolment qualifications and composition of student population will influence the academic level of the courses, the difficulty of the examination, the grading standards, recruitment of students and the academic milieu. Will the result be lower standards and grade inflation at campus A while the instructors will lose some of their motivation at campus B and C? This can be explored in future studies.

This study is based on access to administrative data, and it is likely that many unobserved factors have impacted the results. This can explain why the adjusted $\mathrm{R}^{2}$ is rather low and the different values of the independent variables associated with success at the different schools. There can be differences in the quality of instructors and their judgement, students' level of effort and personal characteristics and the design of both the course and of the exam format. No data are available to check whether the composition of students from different schools/campuses were the same in 2019 as in 2016-2017, but it is a plausible assumption since the composition had been quite stable over a long period of time.

This analysis shows that GPA, mathematical background and gender are good predictors for performance in business courses. There is a substantial gender distinction between quantitative and non-quantitative courses. Male students have more success than female peers in quantitative course, while the situation is the opposite for non-quantitative courses where the women get higher scores than the men.

The main contribution of this paper was to investigate grade practices between different schools offering the same subject. Despite the national intention to have an equal award system that is independent of the composition of the student body and the colleges, this study reveals a substantial variation in grade standards. Small colleges with academically weaker students tend 
to have softer grading practices and considerable variety in grade evaluation, depending upon the instructor.

\section{Declaration of Conflicting Interests and Ethics}

The author declares no conflict of interest. This research study complies with research publishing ethics. The scientific and legal responsibility for manuscripts published in IJATE belongs to the author.

\section{ORCID}

Leiv Opstad (iD https://orcid.org/0000-0003-2400-6581

\section{REFERENCES}

Alcock, J., Cockcroft. S., \& Frank, F. (2008). Quantifying the advantage of secondary mathematics study for accounting and finance undergraduates. Accounting \& Finance, 48(5), 697-718.

Bagues, M., Labini, M. S., \& Zinovyeva, N. (2008). Differential grading standards and university funding: Evidence from Italy. CESifo Economic Studies, 54(2), 149-176. https://doi.org/10.1093/cesifo/ifn011

Ballard, C. L., \& Johnson, M. F. (2004). Basic math skills and performance in an introductory economics class. The Journal of Economic Education, 35(1), 3-23. https://doi.org/10.32 00/JECE.35.1.3-23

Bardach, L., \& Klassen, R. M. (2020). Smart teachers, successful students? A systematic review of the literature on teachers' cognitive abilities and teacher effectiveness. Educational Research Review, 30, 100312. https://doi.org/10.1016/j.edurev.2020.100312

Beenstock, M., \& Feldman, D. (2018). Decomposing university grades: A longitudinal study of students and their instructors. Studies in Higher Education, 43(1), 114-133. https://doi.org/10.1080/03075079.2016.1157858

Blaylock, A., \& Lacewell, S. K. (2008). Assessing prerequisites as a measure of success in a principles of finance course. Academy of Educational Leadership Journal, 12(1), 51.

Bonesrønning, H. (1999). The variation in teachers' grading practices: Causes and consequences. Economics of Education Review, 18(1), 89-106. https://doi.org/10.1016/s $\underline{0272-7757(98) 00012-0}$

Bonesrønning, H. and Opstad, L. (2012). How much is students' college performance affected by quantity of study? International Review of Economics Education, 11(2), 46-63. https://doi.org/10.1016/s1477-3880(15)30012-8

Borde, S. F. (2017). Student characteristics and performance in intermediate corporate finance. Journal of Financial Education, 43(1), 1-13.

Brookhart, S. M., Guskey, T. R., Bowers, A. J., McMillan, J. H., Smith, J. K., Smith, L. F., \& Welsh, M. E. (2016). A century of grading research: Meaning and value in the most common educational measure. Review of Educational Research, 86(4), 803-848. https:// doi.org/10.3102/0034654316672069

Brookshire, R. G., \& Palocsay, S. W. (2005). Factors contributing to the success of undergraduate business students in management science courses. Decision Sciences Journal of Innovative Education, 3(1), 99-108. https://doi.org/10.1111/j.15404609.2005.00054.x

Cheng, L., DeLuca, C., Braund, H., Yan, W., \& Rasooli, A. (2020). Teachers' grading decisions and practices across cultures: Exploring the value, consistency, and construction of grades across Canadian and Chinese secondary schools. Studies in Educational Evaluation, 67, 100928. https://doi.org/10.1016/j.stueduc.2020.100928

Chevalier, A. (2002). Education, motivation and pay of UK graduates: Are they different for women? European Journal of Education, 37(4), 347-369. 
Darling-Hammond, L. (2000). Teacher quality and student achievement. Education Policy Analysis Archives, 8(1), 1-44. https://doi.org/10.14507/epaa.v8n1.2000

Friday, E., Friday-Stroud, S. S., Green, A. L., \& Hill, A. Y. (2006). A multi-semester comparison of student performance between multiple traditional and online sections of two management courses. Journal of Behavioral \& Applied Management, 8(1), 66-81. https://doi.org/10.1108/00251740510589742

Grove, W. A., Wasserman, T., \& Grodner, A. (2006). Choosing a proxy for academic aptitude. The Journal of Economic Education, 37(2), 131-147. https://doi.org/10.3200/J ECE.37.2.131-147

Godor, B. P. (2017). Revisiting differential grading standards anno 2014: An exploration in Dutch higher education. Assessment \& Evaluation in Higher Education, 42(4), 596-606. https://doi.10.1080/02602938.2016.1173186

Hoefer, P., Yurkiewicz, J., \& Byrne, J. C. (2012). The association between students' evaluation of teaching and grades. Decision Sciences Journal of Innovative Education, 10(3), 447459. https://doi.org/10.1111/j.1540-4609.2012.00345

Johnson, M., Robson, D., \& Taengnoi, S. (2014). A meta-analysis of the gender gap in performance in collegiate economics courses. Review of Social Economy, 72(4), 436-459.

Jones, C. T., Kouliavtsev, M. S., \& Ethridge Jr, J. R. (2013). Lower level prerequisites and student performance in intermediate business courses: Does it matter where students take their principles courses? Journal of Education for Business, 88(4), 238-245. https://doi.org/10.1080/08832323.2012.688777

Krishna, A., \& Orhun, A. Y. (2020). EXPRESS: Gender (Still) matters in business school. Journal of Marketing Research. https://doi.org/10.0022243720972368

Lawrence, J. J., \& Pharr, S. (2003). Evolution of admission standards in response to curriculum integration. Quality Assurance in Education, 11(4), 222-233. https://doi.org/10.1108/09 $\underline{684880310501403}$

Mallik, G., \& Lodewijks, J. (2010). Student performance in a large first year economics subject: Which variables are significant? Economic Papers: A Journal of Applied Economics and Policy, 29(1), 80-86. https://doi.org/10.1111/j.1759-3441.2010.00051.x

Marcal, L. E., Hennessey, J. E., Curren, M. T., \& Roberts, W. W. (2005). Do business communication courses improve student performance in introductory marketing?, Journal of Education for Business, 80(5), 289-294. https://doi.org/10.3200/JOEB.80.5.2 $\underline{89-294}$

Marini, J., Shaw, E., Young, L., \& Ewing, M. (2018). Getting to know your criterion: Examining college course grades and GPAs over time. The College Board. Retrieved from https://files.eric.ed.gov/fulltext/ED582569.pdf

Mavruk, T. (2019). Do men outperform women in finance classes? Journal of International Business Education, 14, 75-98.

Mayer-Foulkes, D. (2002). On the dynamics of quality student enrollment at institutions of higher education. Economics of Education Review, 21(5), 481-489. https://doi.org/10.10 16/S0272-7757(01)00036-X

Møen, J., \& Tjelta, M. (2010). Grading standards, student ability and errors in college admission. Scandinavian Journal of Educational Research, 54(3), 221-237. https://doi.o $\mathrm{rg} / 10.1080 / 00313831003764503$

Odden, A., Borman, G., \& Fermanich, M. (2004). Assessing teacher, classroom, and school effects, including fiscal effects. Peabody Journal of Education, 79(4), 4-32. https://doi.o $\mathrm{rg} / 10.1207 / \mathrm{s} 15327930 \mathrm{pje} 7904 \_7$

Opstad, L. (2018). Success in business studies and mathematical background: The case of Norway. Journal of Applied Research in Higher Education, 10(3), 399-408. https://doi.org/10.1108/JARHE-11-2017-0136 
Opstad, L. (2020). Why are there different grading practices based on students' choice of business major? Educational Process: International Journal, 9(1), 43-57. https://doi.org /10.22521/edupij.2020.91.3

Opstad, L., \& Årethun, T. (2019). Factors influencing students' choice of mathematical level at high school and the impact this has on performance on business courses in Norway. WEI International Academic Conference Proceedings 2019, WestEastInstitute, 28-40.

Opstad, L., \& Årethun, T. (2020a). Skills, gender, and performance matter when undergraduate business students choose specialisation within business courses.International Journal of Management, Knowledge and Learning, 9(1), 95-107.

Opstad, L., \& Årethun, T. (2020b). Factors that explain undergraduate business students' performance in their chosen field. Does gender matter? Global Conference on Business and Finance Proceedings, 15(2), 2-21.

Stinebrickner, R., \& Stinebrickner, T.R. (2008). The causal effect of studying on academic performance. The BE Journal of Economic Analysis \& Policy, 8(1), 1-53. https://doi.org 110.2202/1935-1682.1868

Trapman, S., Hell, B., Hirn, J. W., \& Schuler, H. (2007). Meta-analysis of the relationship between the big five and academic success at university. Journal of Psychology, 215, 132151. https://doi.org/10.1037/e518532013-271

Uyar, A., \& Güngörmüş. A. H. (2011). Factors associated with student performance in financial accounting course. European Journal of Economic \& Political Studies, 4(2), 139-154.

Volchok, E. (2019). Differences in the performance of male and female students in partially online courses at a community college. Community College Journal of Research and Practice, 43(12), 904-920. https://doi.org/10.1080/10668926.2018.1556134

Walstad, W. B., \& Miller, L. A. (2016). What's in a grade? Grading policies and practices in principles of economics. The Journal of Economic Education, 47(4), 338-350. https://doi.org/10.1080/00220485.2016.1213683 